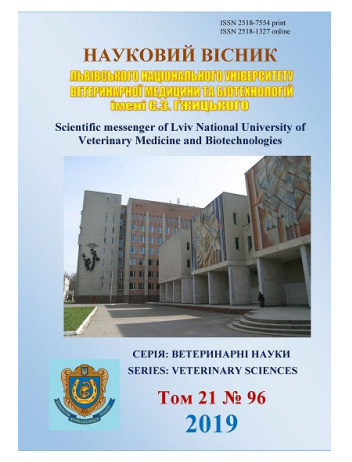

\author{
Науковий вісник Дьвівського національного університету \\ ветеринарної медицини та біотехнологій імені С.3. Гжицького. \\ Серія: Ветеринарні науки
}
Scientific Messenger of Lviv National University of Veterinary Medicine and Biotechnologies. Series: Veterinary sciences

\title{
Epizootiology of Infectious Diseases of Dog in Some States in Nigeria (2015- 2018)
}

M.T. Tion ${ }^{1,2}$, G.A. Zon ${ }^{2}$, H.A. Fotina ${ }^{2}$, K.I. Ogbu ${ }^{3}$, S.A. Nguetyo ${ }^{1}$, A.A. Amine ${ }^{1}$, J.O. Oochi ${ }^{1}$, M.T. Ojeamiren ${ }^{1}$, A.A. Saganuwan ${ }^{1}$

${ }^{I}$ College of Veterinary Medicine, University of Agriculture, Makurdi, Benue State, Nigeria

${ }^{2}$ Sumy National Agrarian University, Sumy, Ukraine

${ }^{3}$ Federal College of Animal Health and Production Technology, National Veterinary Research Institute Vom, Plateau State, Nigeria

\author{
Article info \\ Received 01.10.2019 \\ Received in revised form \\ 03.11 .2019 \\ Accepted 04.11.2019 \\ College of Veterinary Medicine, \\ University of Agriculture, Makurdi, \\ Benue State, Nigeria. \\ Tel.: +234-803-723-98-72 \\ +234-705-859-89-93 \\ E-mail:tions_doc@yahoo.co.uk \\ Sumy National Agrarian \\ University, Herasima \\ Kondratieva Str., 160, \\ Sumy, 40000, Ukraine. \\ Federal College of Animal Health \\ and Production Technology, \\ National Veterinary Research \\ Institute Vom, Plateau State, \\ Nigeria.
}

Tion, M.T., Zon, G.A., Fotina, H.A., Ogbu, K.I., Nguetyo, S.A., Amine, A.A., Oochi, J.O., Ojeamiren, M.T., \& Saganuwan, A.A. (2019). Epizootiology of Infectious Diseases of Dog in Some States in Nigeria (2015-2018). Scientific Messenger of Lviv National University of Veterinary Medicine and Biotechnologies. Series: Veterinary sciences, 21(96), 33-40. doi: 10.32718/nvlvet9606

An epizootiology of infectious diseases/conditions of dog in some veterinary clinics from Benue, Plateau states and the Federal Capital Territory in Nigeria were assessed from 2015 to 2018. This study revealed about seventeen (17) infectious clinical cases/conditions from 1865 cases recorded within the period of four (4) years. These comprised of helminthoses (17.8\%) having the highest prevalence followed by babesiosis (17.5\%), parvovirosis (15.9\%), ectoparasitism (11.3\%), scepticemia (6.9\%), Mange (5.7\%), urinary tract infections $(4.7 \%)$, canine distemper $(4.2 \%)$, colitis $(3.9 \%)$, myiasis $(2.7 \%)$, trypanosomosis $(2.1 \%)$, leptospirosis and transmissible venereal tumor (1.9\%), respiratory infections (1.7\%), otitis (1.0\%) and orchitis (0.7\%). Puppies (0-6 months old) 50.2\% were mostly affected. Incidences of diseases were more in Alsatians (23.7\%), Cross (22.9\%), Nigerian indigenous breed (20.5\%), Caucasian (9.6\%) and Rottweiler (8.9\%). More cases of vaccinated (68.7\%) were recorded against the unvaccinated $(31.3 \%)$ dogs while male (57.1\%) dogs had a higher frequency of cases as compared with their female (42.9\%) counterpart. Disease incidence was highest in dry season (54.3\%) especially in the months of December (13.3\%), January (11.1\%) and February (10.6\%).The highest frequency of disease incidence was recorded in 2015 (36.4\%). Most the infectious clinical cases/conditions recorded from this study were preventable cases demanding veterinary care in order to prevent the risk of zoonosis.

Key words: Epizootiology, dog, incidence, infectious diseases, Nigeria.

\section{Introduction}

The most successful canids domesticated by man worldwide are the 'dog' and they have supported physically, socially and emotionally to owners and above all to children (Dohoo et al., 1998; Robertson et al., 2000). The specie of animal that has resided passionately with humans for over 30, 000 years is the canid ( $\operatorname{dog}$ ) (Thalmann et al., 2013) and have developed a specific skill of communication with humans (Kaminski \& Nitzschner, 2013).

Large populations of dogs have come in close contact with human population in developing countries, with the lack of veterinary attention and zoonotic awareness do increase the risk of disease transmission (Traub et al., 2005). Domestic dog (Canis familiaris) are ubiquitous, with free-roaming and scavenging lifestyles, thus exposing them to multiple pathogens and facilitating their contact with susceptible individuals resulting in disease conditions (Cleaveland et al., 2006).

Several diseases and clinical conditions that have negative effect on the health of domesticated animals also affect dogs too. Dog keeping is associated with certain responsibilities including the provision of shelter, nutrition, good health care, disease management, as well as protecting humans from zoonotic diseases associated with it (Craig \& MacPherson, 2000). There are some reports on diseases/clinical conditions of dogs in Nigeria by some researchers (William et al., 2002; Okusanya et al., 2014, Shima et al., 2015). Investigation of diseases/clinical conditions of dogs presented to the 
veterinary clinics in some selected states in Nigeria for treatment triggered this epizootiological analysis.

\section{Materials and Methods}

This retrospective study was conducted in Benue, Plateau States and Abuja \{Federal Capital Territory (FCT) $\}$, Nigeria over a period of four years (2015-2018).

Data of diagnosed clinical cases/conditions of dogs presented at the various veterinary clinics were collected in Nigeria from two states and FCT namely; Plateau state (Jos; Geographic coordinates: 9०55'3.045"N, 8०53'52.584"E; altitude: $1184 \mathrm{~m}$ a.s.l), Benue state (Makurdi; $7^{\circ} 43^{\prime} 52.548^{\prime \prime} \mathrm{N}, 8^{\circ} 32^{\prime} 18.33^{\prime \prime} \mathrm{E} ; 90 \mathrm{~m}$ a.s.l) and in the Federal Capital Territory (Abuja; 9 $3^{\prime} 51.59^{\prime \prime} \mathrm{N}$, 7²9'21.47"E; $482 \mathrm{~m}$ a.s.l) from 2015 to 2018 were assessed. History, clinical signs, diagnosis (which was both presumptive and definitive) and therapeutic regimens of diseases/clinical cases were reviewed. The presented signs, vaccination status, treatment outcome, sex, breeds and age of dogs were recorded. The status of the vaccination history was categorized as vaccinated (i.e. complete and incomplete) and unvaccinated (where vaccination was majorly against parvovirus, distemper, hepatitis, leptospirosis, parainfluenza and rabies). Similarly, the treatment outcomes of the cases following medical intervention were classified as either - recovered or dead.

The distribution patterns of the cases were according to age, sex, vaccination status, treatment outcome, and season. The data obtained were then summarized as proportional incidence rates of breed, month and year of occurrence using percentage and presented in tabular format using Microsoft Office Excel (2010) for descriptive analysis.

\section{Results}

\section{Table 1}

The prevalence of clinical diseases/conditions according age, sex, and vaccination status and treatment outcome between 2015-2018

\begin{tabular}{lcc}
\hline \multirow{2}{*}{ GROUPS } & \multicolumn{2}{c}{$\begin{array}{c}\text { CLINICAL DISEASES/ } \\
\text { CONDITIONS }\end{array}$} \\
\cline { 2 - 3 } & Frequency (n) & Percentage (\%) \\
\hline AGE & 936 & 50.2 \\
$0-6$ months & 354 & 19.0 \\
7-12 months & 575 & 30.8 \\
$>12$ months & & \\
\hline SEX & 1064 & 57.1 \\
Male & 801 & 42.9 \\
Female & & \\
VACCINATION STATUS & 1281 & 68.7 \\
Vaccinated & 584 & 31.3 \\
Unvaccinated & & \\
\hline TREATMENT OUTCOME & 1788 & 95.9 \\
Recovered & 77 & 4.1 \\
Dead & & \\
\hline SEASON & 1012 & 54.3 \\
Dry (November-March) & 853 & 45.7 \\
Wet (April-October) &
\end{tabular}

Table 2

The incidence of clinical diseases/conditions according to breed of dogs (2015-2018)

\begin{tabular}{|c|c|c|c|c|c|c|c|c|c|c|}
\hline \multirow{2}{*}{$\begin{array}{l}\text { Clinical diseases/ } \\
\text { conditions }\end{array}$} & \multirow{2}{*}{$\begin{array}{l}\text { Total } \\
\text { N (\%) }\end{array}$} & \multicolumn{9}{|c|}{ BREEDS OF DOGS } \\
\hline & & NIB & Cross & Alsatian & Caucasian & Rottweiler & Toys & Mastiffs & Boerboel & Others \\
\hline \multicolumn{11}{|c|}{ A) Parasitic diseases } \\
\hline Helminthoses & $332(17.8)$ & 63 & 53 & 40 & 37 & 33 & 21 & 29 & 19 & 37 \\
\hline Ectoparasitism & $201(11.3)$ & 44 & 38 & 65 & 31 & 10 & 0 & 5 & 2 & 6 \\
\hline Mange & $106(5.7)$ & 37 & 51 & 11 & 2 & 3 & 0 & 0 & 0 & 2 \\
\hline Myiasis & $51(2.7)$ & 31 & 11 & 2 & 5 & 0 & 0 & 0 & 0 & 2 \\
\hline \multicolumn{11}{|c|}{ Viral diseases } \\
\hline Parvovirosis & $296(15.9)$ & 57 & 58 & 73 & 41 & 61 & 0 & 1 & 0 & 5 \\
\hline Canine Distemper & $79(4.2)$ & 6 & 19 & 27 & 9 & 16 & 0 & 0 & 0 & 2 \\
\hline TVT & $35(1.9)$ & 19 & 12 & 0 & 0 & 0 & 0 & 0 & 0 & 4 \\
\hline Rabies & $12(0.6)$ & 7 & 2 & 0 & 0 & 0 & 0 & 0 & 0 & 3 \\
\hline \multicolumn{11}{|c|}{ B) Protozoan diseases } \\
\hline Babesiosis & $327(17.5)$ & 58 & 83 & 97 & 25 & 30 & 2 & 16 & 6 & 10 \\
\hline Trypanosomosis & $39(2.1)$ & 6 & 7 & 15 & 7 & 1 & 0 & 0 & 0 & 3 \\
\hline \multicolumn{11}{|c|}{ Bacterial diseases } \\
\hline${ }^{+}$Septicemia & $129(6.9)$ & 19 & 27 & 62 & 3 & 11 & 1 & 2 & 2 & 2 \\
\hline Leptospirosis & $35(1.9)$ & 6 & 3 & 9 & 5 & 0 & 0 & 5 & 0 & 7 \\
\hline \multicolumn{11}{|c|}{ Multicausal diseases } \\
\hline UTI & $87(4.7)$ & 19 & 43 & 11 & 5 & 0 & 0 & 6 & 3 & 0 \\
\hline Colitis & $73(3.9)$ & 5 & 7 & 13 & 0 & 0 & 30 & 3 & 5 & 10 \\
\hline Respiratory Infections & $31(1.7)$ & 3 & 9 & 7 & 3 & 2 & 4 & 0 & 3 & 0 \\
\hline Otitis & $19(1.0)$ & 2 & 5 & 7 & 0 & 0 & 2 & 0 & 0 & 3 \\
\hline Orchitis & $13(0.7)$ & 1 & 0 & 5 & 6 & 0 & 0 & 0 & 0 & 1 \\
\hline $\begin{array}{r}\text { TOTAL (N) } \\
(\%)\end{array}$ & & $\begin{array}{c}383 \\
(20.5)\end{array}$ & $\begin{array}{c}428 \\
(22.9)\end{array}$ & $\begin{array}{c}444 \\
(23.7)\end{array}$ & $\begin{array}{l}179 \\
(9.6)\end{array}$ & $\begin{array}{c}167 \\
(8.9)\end{array}$ & $\begin{array}{c}69 \\
(3.7)\end{array}$ & $\begin{array}{c}67 \\
(3.5)\end{array}$ & $\begin{array}{c}40 \\
(2.1)\end{array}$ & $\begin{array}{c}97 \\
(5.2)\end{array}$ \\
\hline
\end{tabular}

Key: $\mathrm{NIB}=$ Nigerian indigenous breed; TVT $=$ Transmissible Venereal Tumor; UTI $=$ Urinary Tract Infections, ${ }^{+}$Septicemia $=$from bacterial origin 
Table 3

The incidence of clinical diseases/conditions according to years (2015-2018)

\begin{tabular}{|c|c|c|c|c|c|c|}
\hline Clinical diseases/ conditions & Tot: & $(\%)$ & 2015 & 2016 & 2017 & 2018 \\
\hline \multicolumn{7}{|c|}{ A) Parasitic diseases } \\
\hline Helminthoses & \multicolumn{2}{|c|}{$332(17.8)$} & $122(6.4)$ & $91(4.8)$ & $66(3.5)$ & $53(2.9)$ \\
\hline Ectoparasitism & \multicolumn{2}{|c|}{$201(10.7)$} & $72(3.9)$ & $46(2.5)$ & $49(2.5)$ & $34(1.8)$ \\
\hline Mange & \multicolumn{2}{|c|}{$106(5.7)$} & $63(3.4)$ & $26(1.4)$ & $9(0.5)$ & $8(0.4)$ \\
\hline Myiasis & \multicolumn{2}{|c|}{$51(2.8)$} & $19(1)$ & $23(1.2)$ & $5(0.3)$ & $4(0.2)$ \\
\hline Total N & 690 & 37.0 & $276(14.7)$ & & & \\
\hline \multicolumn{7}{|c|}{ Viral diseases } \\
\hline Parvovirosis & \multicolumn{2}{|c|}{$296(15.9)$} & $103(5.5)$ & $41(2.2)$ & $113(6.1)$ & $39(2.1)$ \\
\hline Canine Distemper & \multicolumn{2}{|c|}{$79(4.2)$} & $37(2)$ & $21(1.1)$ & $11(0.6)$ & $10(0.5)$ \\
\hline Transmissible Venereal Tumor & \multicolumn{2}{|c|}{$35(1.9)$} & $18(1)$ & $9(0.5)$ & $2(0.1)$ & $6(0.3)$ \\
\hline Rabies & \multicolumn{2}{|c|}{$12(0.6)$} & $4(0.2)$ & $1(0.1)$ & $1(0.1)$ & $6(0.3)$ \\
\hline Total N & 422 & 22.6 & & & & \\
\hline \multicolumn{7}{|c|}{ B) Protozoan diseases } \\
\hline Babesiosis & \multicolumn{2}{|c|}{$327(17.5)$} & $112(6)$ & $55(3)$ & $39(2.1)$ & $121(6.5)$ \\
\hline Trypanosomosis & \multicolumn{2}{|c|}{$39(2.1)$} & $16(0.9)$ & $14(0.8)$ & $6(0.3)$ & $3(0.2)$ \\
\hline Total N & 366 & 19.6 & & & & \\
\hline \multicolumn{7}{|c|}{ Bacterial diseases } \\
\hline${ }^{+}$Septicemia & \multicolumn{2}{|c|}{$129(6.9)$} & $51(2.7)$ & $33(1.7)$ & $28(1.5)$ & $17(0.9)$ \\
\hline Leptospirosis & \multicolumn{2}{|c|}{$35(1.9)$} & $3(0.2)$ & $9(0.5)$ & $8(0.4)$ & $15(0.8)$ \\
\hline Total N & 164 & 8.8 & & & & \\
\hline \multicolumn{7}{|c|}{ Multicausal diseases } \\
\hline Urinary Tract Infections & \multicolumn{2}{|c|}{$87(4.7)$} & $36(1.9)$ & $25(1.3)$ & $19(1)$ & $7(0.4)$ \\
\hline Colitis & \multicolumn{2}{|c|}{$73(3.9)$} & $5(0.3)$ & $10(0.5)$ & $27(1.5)$ & $31(1.7)$ \\
\hline Respiratory Infections & \multicolumn{2}{|c|}{$31(1.7)$} & $10(0.5)$ & $7(0.4)$ & $11(0.6)$ & $3(0.2)$ \\
\hline Otitis & \multicolumn{2}{|c|}{$19(1.0)$} & $7(0.4)$ & $0(0)$ & $2(0.1)$ & $10(0.5)$ \\
\hline Orchitis & \multicolumn{2}{|c|}{$13(0.7)$} & $2(0.1)$ & $3(0.2)$ & $1(0.1)$ & $7(0.4)$ \\
\hline Total N & 223 & 12.0 & & & & \\
\hline TOTAL (N) & & & (36.4) & 414 (22.2) & $(21.3)$ & $374 \quad(20.1)$ \\
\hline
\end{tabular}

Table 4

The incidence of clinical diseases/conditions according to Months (2015-2018)

\begin{tabular}{|c|c|c|c|c|c|c|c|c|c|c|c|c|c|}
\hline Clinical diseases/ conditions & Total N (\%) & 1 & 2 & 3 & 4 & 5 & 6 & 7 & 8 & 9 & 10 & 11 & 12 \\
\hline \multicolumn{14}{|c|}{ A) Parasitic diseases } \\
\hline Helminthosis & $332(17.8)$ & 41 & 32 & 30 & 23 & 19 & 19 & 11 & 34 & 29 & 25 & 33 & 36 \\
\hline Ectoparasitism & $201(11.3)$ & 11 & 6 & 12 & 8 & 6 & 32 & 19 & 22 & 27 & 17 & 15 & 26 \\
\hline Mange & $106(5.7)$ & 12 & 9 & 15 & 2 & 9 & 8 & 5 & 7 & 4 & 8 & 8 & 19 \\
\hline Myiasis & $51(2.7)$ & 7 & 10 & 6 & 4 & 2 & 3 & 4 & 1 & 1 & 5 & 2 & 6 \\
\hline \multicolumn{14}{|c|}{ Viral diseases } \\
\hline Canine Parvovirus & $296(15.9)$ & 36 & 40 & 13 & 5 & 12 & 27 & 29 & 11 & 17 & 33 & 32 & 41 \\
\hline Canine Distemper & $79(4.2)$ & 8 & 11 & 2 & 0 & 0 & 7 & 2 & 4 & 15 & 2 & 9 & 19 \\
\hline TVT & $35(1.9)$ & 6 & 0 & 8 & 0 & 2 & 0 & 0 & 0 & 6 & 0 & 2 & 11 \\
\hline Rabies & $12(0.6)$ & 0 & 1 & 0 & 0 & 1 & 1 & 0 & 2 & 4 & 0 & 0 & 3 \\
\hline \multicolumn{14}{|c|}{ B) Protozoan diseases } \\
\hline Babesiosis & $327(17.5)$ & 41 & 31 & 22 & 11 & 9 & 31 & 36 & 39 & 20 & 23 & 27 & 37 \\
\hline Trypanosomosis & $39(2.1)$ & 5 & 0 & 4 & 3 & 1 & 0 & 11 & 5 & 4 & 0 & 2 & 4 \\
\hline \multicolumn{14}{|c|}{ Bacterial diseases } \\
\hline${ }^{+}$Septicemia & $129(6.9)$ & 13 & 11 & 19 & 5 & 2 & 3 & 17 & 6 & 19 & 7 & 12 & 15 \\
\hline Leptospirosis & $35(1.9)$ & 1 & 8 & 0 & 2 & 2 & 1 & 5 & 0 & 2 & 0 & 6 & 8 \\
\hline \multicolumn{14}{|c|}{ Multicausal diseases } \\
\hline UTI & $87(4.7)$ & 3 & 19 & 8 & 0 & 0 & 14 & 11 & 9 & 3 & 7 & 2 & 11 \\
\hline Colitis & $73(3.9)$ & 13 & 10 & 6 & 7 & 0 & 4 & 0 & 2 & 12 & 3 & 7 & 9 \\
\hline Respiratory Infections & $31(1.7)$ & 9 & 8 & 5 & 2 & 0 & 0 & 0 & 2 & 0 & 1 & 2 & 2 \\
\hline Otitis & $19(1.0)$ & 0 & 2 & 3 & 0 & 3 & 1 & 5 & 0 & 0 & 2 & 2 & 1 \\
\hline Orchitis & $13(0.7)$ & 0 & 2 & 0 & 0 & 2 & 0 & 5 & 0 & 3 & 0 & 1 & 0 \\
\hline $\begin{array}{r}\text { TOTAL (N) } \\
(\%)\end{array}$ & 1865 & $\begin{array}{l}206 \\
(11.1\end{array}$ & $\begin{array}{l}200 \\
(10.6\end{array}$ & $\begin{array}{l}153 \\
(8.2)\end{array}$ & $\begin{array}{l}72 \\
(3.9)\end{array}$ & $\begin{array}{l}70 \\
(3.8)\end{array}$ & $\begin{array}{l}151 \\
(8.1)\end{array}$ & $\begin{array}{l}160 \\
(8.6)\end{array}$ & $\begin{array}{l}144 \\
(7.7)\end{array}$ & $\begin{array}{l}166 \\
(8.9)\end{array}$ & $\begin{array}{l}133 \\
(7.1)\end{array}$ & $\begin{array}{l}162 \\
(8.7)\end{array}$ & $\begin{array}{l}248 \\
(13.3)\end{array}$ \\
\hline
\end{tabular}

Key:1=January, 2= February, 3= March, 4= April, 5= May, 6= June, 7= July, 8= August, 9= September, 10= October, 11= November and $12=$ December; TVT $=$ Transmissible Venereal Tumor, UTI $=$ Urinary Tract Infections; ${ }^{+}$Septicemia $=$from bacterial origin Dry season $($ November- March $)=11.1+10.6+8.2+8.7+13.3=51.9 \%$ 
Wet season (April- October) $=3.9+3.8+8.1+8.6+7.7+8.9+7.1=48.1 \%$

Table 5

Summarized data of incidences of clinical cases/conditions according to season (2015-2018)

\begin{tabular}{lcccc}
\hline \multirow{2}{*}{\multicolumn{1}{c}{ Diseases }} & \multicolumn{4}{c}{ Seasons } \\
\cline { 2 - 5 } & \multicolumn{3}{c}{ Dry } & \multicolumn{3}{c}{ Wet } \\
\cline { 2 - 5 } & Frequency Percentage & Frequency & Percentage \\
& $(\mathrm{N})$ & $17)$ & $(\mathrm{N})$ & $(\%)$ \\
\hline Helminthoses & 172 & 17.8 & 160 & 17.9 \\
Ectoparasitism & 70 & 7.2 & 131 & 14.6 \\
Mange & 63 & 6.5 & 43 & 4.8 \\
Myiasis & 31 & 3.2 & 20 & 2.2 \\
Parvovirosis & 162 & 16.7 & 134 & 15 \\
Canine distemper & 49 & 5.1 & 30 & 3.3 \\
Transmissible & 27 & 2.8 & 8 & 0.9 \\
venereal tumor & & & & \\
Rabies & 4 & 0.4 & 8 & 0.9 \\
Babesiosis & 158 & 16.3 & 169 & 18.9 \\
Trypanosomosis & 15 & 1.6 & 24 & 2.7 \\
Scepticemia & 70 & 7.2 & 59 & 6.6 \\
Leptospirosis & 23 & 2.4 & 12 & 1.3 \\
Urinary tract & 43 & 4.4 & 44 & 4.9 \\
infections & & & & \\
Colitis & 45 & 4.6 & 28 & 3.1 \\
Respiratory & 26 & 2.7 & 5 & 0.6 \\
infections & & & & \\
Otitis & 8 & 0.8 & 11 & 1.2 \\
Orchitis & 3 & 0.3 & 10 & 1.1 \\
\hline
\end{tabular}

Table 6

The minimum, mean and maximum clinical diseases/conditions in Nigeria (2015-2018)

\begin{tabular}{|c|c|c|c|}
\hline $\begin{array}{l}\text { Clinical diseases/ } \\
\text { conditions }\end{array}$ & Minimum & Mean & Maximum \\
\hline \multicolumn{4}{|c|}{ Parasitic diseases } \\
\hline Helminthoses & 53 & 83 & 122 \\
\hline Ectoparasitism & 34 & 50.3 & 72 \\
\hline Mange & 8 & 26.5 & 63 \\
\hline Myiasis & 4 & 12.8 & 23 \\
\hline \multicolumn{4}{|c|}{ Viral diseases } \\
\hline Parvovirosis & 39 & 74 & 113 \\
\hline Canine Distemper & 10 & 19.8 & 37 \\
\hline Transmissible & 2 & 8.8 & 18 \\
\hline Venereal Tumor & & & \\
\hline Rabies & 1 & 3 & 6 \\
\hline \multicolumn{4}{|c|}{ Protozoan diseases } \\
\hline Babesisosis & 39 & 81.8 & 121 \\
\hline Trypanosomosis & 3 & 9.8 & 16 \\
\hline \multicolumn{4}{|c|}{ Bacterial diseases } \\
\hline${ }^{+}$Septicemia & 17 & 32.3 & 51 \\
\hline Leptospirosis & 3 & 8.8 & 15 \\
\hline \multicolumn{4}{|c|}{ Multicausal diseases } \\
\hline $\begin{array}{l}\text { Urinary } \\
\text { Infections }\end{array}$ & 7 & 21.8 & 36 \\
\hline Colitis & 5 & 18.3 & 31 \\
\hline Respiratory Infections & 3 & 7.8 & 11 \\
\hline Otitis & 0 & 4.8 & 10 \\
\hline Orchitis & 1 & 3.3 & 7 \\
\hline
\end{tabular}

\section{Discussion}

Out of 1865 diagnosed clinical diseases/cases presented at the various veterinary clinics in Benue, Plateau and Abuja in Nigeria for a period of 4 years (i.e 2015-2018), 17 infectious clinical cases/conditions were recorded with helminthoses $(17.8 \%)$ having the highest prevalence followed by babesiosis $(17.5 \%)$, parvovirosis (15.9\%), ectoparasitism (11.3\%), scepticemia (6.9\%), mange $(5.7 \%)$, UTI $(4.7 \%)$, canine distemper $(4.2 \%)$, colitis $(3.9 \%)$, myiasis $(2.7 \%)$, trypanosomosis $(2.1 \%)$, leptospirosis and TVT $(1.9 \%)$ each, respiratory infections $(1.7 \%)$, otitis $(1.0 \%)$ and orchitis $(0.7 \%)$. Cases were further grouped into various aetiologic causes (i.e. parasitic, viral, protozoan, bacterial and muticausal agents).

From this study, dogs between 0-6 months (puppies) old $(50.2 \%)$ were more affected with clinical cases/conditions as compared to 7-12 months (19.0\%) and $>12$ months old dogs $(30.8 \%)$. This may be as a result of the fact that puppies don't have a well developed immune status (maternally derived antibodies) which eventually begins to wane down at about 12 weeks of age (Mila et al., 2014), thus opening a window for many clinical conditions to occur in them. This finding disagrees with the report according to Shima et al. (2015) that adult dogs had more clinical cases/conditions than puppies and adolescents (Table 1).

The concentration of serum immunoglobulins ( $\mathrm{IgG}$, $\operatorname{IgM}$ and $\operatorname{IgA}$ ) of puppies does not reach full adult levels until 12 months of age (Schreiber et al., 1992). Although the percentage of blood $\mathrm{CD}^{+} \mathrm{T}$-cells remains relatively stable from birth to adulthood in dogs but the percentage of $\mathrm{CD}^{+} \mathrm{T}$-lymphocytes is low at birth and increases with age (Faldyna et al., 2001). These blood lymphocytes are able to respond to stimulation with mitogen but more weakly than cells from adult dogs (Toman et al., 2002). Within the genes of the major histocompatibility complex (MHC) lie the key genetic elements of immune responsiveness; present as the dog leukocyte antigen (DLA) systems. Recent studies of DLA haplotypes and genome-wide screening in the dog have shown distinct breed variation in genetic background (Kennedy et al., 2002). This would suggest variation in dog breeds in immune function, and response to diseases and vaccination (Kennedy et al., 2005). Moreover, there is breed variation in the proportions of blood lymphocyte subsets (Faldyna et al., 2001).

The prevalence of clinical cases/conditions according to sex (Table 1), more males $(57.1 \%)$ than their female $(42.9 \%)$ counterparts were recorded. In Nigeria, dog owners usually house and provide better veterinary care for male dogs than their female counterparts probably due to their use as security while female dogs may be accorded better veterinary attention because of their use for breeding (Shima et al., 2015; Tion et al., 2018).

More cases of vaccinated $(68.7 \%)$ dogs were recorded as compared to those that were not vaccinated $(31.3 \%)$. 
This is as a result of many dog owners especially in these areas where this study was carried have preference for exotic breeds than the NIB which demand high quality veterinary attention as compared to the NIB which are believed to be much hardy in diseases resistance. In Nigeria, vaccination of dogs is usually geared towards killer diseases (parvovirosis, canine distemper, leptospirosis, hepatitis, parainfluenza and rabies). Generally, vaccination stimulates both humoral response through antibody production and cellular responses through B and T lymphocytes (Day, 2012). The duration of immunity is mainly dependent on the degree of immunological memory developed (Schultz et al., 2010; Day, 2012; Jensen et al., 2015). However, it is unclear whether a vaccinated dog is fully protected throughout its life or whether revaccination is always necessary.

Moreso, the presentation of more vaccinated dogs as against the unvaccinated dogs could be as a result of continuous public enlightenment about the need for core vaccinations and routine medical checkup of animals. This study agrees with the findings that vaccinated dogs still come down with diseases (Apaa et al., 2016; Tion et al., 2018). Although, the presence of higher incidence of cases in vaccinated dogs recorded from this study may be related to vaccination failures as a result of poor cold chain, incomplete vaccinations or the unwillingness of low-income dog owners to pay for vaccination or veterinary health care (Mohammed et al., 2005; Dogonyaro, 2010; Nwoha, 2011; Mcree et al., 2014; Shima et al., 2015b; Apaa et al., 2016; Tion et al., 2018).

There was a high recovery $(95.9 \%)$ rate of dogs after treatment outweigh the death rate $(4.1 \%)$ dogs. This finding proves that, most of the treatments given to dogs are effective in order to restore normal physiology. This is in agreement with the report that sick dogs recover to normal healthy condition after receiving appropriate and quality treatment (Tion et al., 2018) (Table 1).

The effect of breed on the incidence of clinical cases/conditions (Table 2) reveal that Alsatian (23.7\%) dogs were more affected with clinical cases/conditions than other breeds. This was followed by Cross $(22.9 \%)$, NIB (20.5\%), Caucasian (9.6\%), Rottweiler (8.9\%), others (5.2\%), Toys (3.6\%), Mastiffs (3.5\%) and Boerboel $(2.1 \%)$. This result agrees with the findings of Shima et al. (2015) who also reported the highest frequency of clinical cases/conditions in Alsatians, NIB, Cross, Rottweiler and Toy breeds respectively. This could be as a result of the increase use of these breeds for security and breeding been responsible for the high incidence of diseases observed in them (Shima et al., 2015), or adaptability of some exotic breed to the local environment and probably due to genetic diversity that makes dogs (NIB) more resistant to some infections (Shima et al., 2015a). High incidences of parasitic diseases (37\%) with helminthoses which recorded the highest frequency and babesiosis $(19.6 \%)$, viral diseases $(22.6 \%)$ have canine parvovirus as the most recorded disease. Multicausal diseases $(12 \%)$ has UTI with the highest frequency while in bacterial diseases $(8.8 \%)$, scepticemia had the highest record of cases as shown in Table 3.
Helminthoses is observed with the highest frequency in NIB then cross, Alsatian, Caucasian and others. The high prevalence of helminthoses among other parasitic diseases recorded in this study is similar to earlier reports about the disease in dogs (Karshima et al., 2010). This may be attributed largely to the differences in their management rather than a reflection of the breed susceptibility. Although the exotic and cross breeds may be less immune to the parasites than the NIB, because of their confined nature and well taken care of, less exposed to helminth infection and less vulnerable to the disease. They also receive good and prompt veterinary care as compared to NIB which usually roams from place to place in search of food and games (Aiyedun \& Olugasa, 2012).

High infestation of ectoparasites among the NIB encountered in the study area was free-ranged and this management practice exposes pets to maximum parasitic infections. This corroborates the views of earlier workers in South Africa (Bryson et al., 2000) and in Nigeria (Nwoke, 2001) while the high frequency in cross and Alsatians may be due to the hairy nature, natural susceptibility to disease conditions and poor veterinary attention/care given by dog owners (Shima et al., 2015).

Parvovirosis, a viral disease has its highest occurrence in Alsatians, Rottweiler, cross, NIB and Caucasian, even though the disease has no predilection for breed. This agrees with the findings that the breeds mentioned above are at risk of contracting the disease (Tion et al., 2018). Babesiosis was observed more in Alsatians, cross and NIB. This is attributed to the presence of ectoparasites witnessed in these breeds (Table 2) that could serve as vectors for protozoan pathogens (Alcaíno et al., 2002; Heukelbach et al., 2012; Nuchjangreed \& Somprasong, 2007). Canine babesiosis is a parasitic disease caused by haemoprotozoan of the genus Babesia and transmitted by an ectoparasite 'hard tick' (Cassini et al., 2009).

The incidences of clinical cases/conditions according to year (Table 3) show that 2015 (36.4\%) had the highest frequency of cases as against 2016 (22.2\%), 2017 (21.3\%) and $2018(20.1 \%)$. This implies that the incidences of clinical cases/conditions were reducing over the years. This maybe as a result of public enlightenment on veterinary services, improvement in the way cases are been diagnosed owing to the presence of better diagnostic tools and continuing education of veterinarians to upgrade their knowledge of cases. Helminthoses (6.4\%), ectoparasitism $(3.9 \%)$, mange $(3.4 \%)$, canine parvovirus $(5.5 \%)$, piroplasmosis $(6 \%)$, septicemia $(2.7 \%)$ and UTI $(1.9 \%)$ respectively were the most predominant cases in the 2015(Table 3) but their gradual reduction over the years proved that better health care and veterinary attention was provided for animal welfare. Piroplasmosis later increased to the highest frequency in 2018 (6.5\%). This may be attributed to poor veterinary attention/care given by dog owners due to financial reasons. The global economic recession post-2008 has had further impact on the uptake of preventive healthcare by pet owners in developed countries and survey data suggests a recent decline in vaccination (Anon 2013a). 
The effect of months and season on the clinical cases/conditions (Table 4) reveals that more cases were recorded in December $(13.3 \%)$ followed by January (11.1\%), February (10.6\%), November $(8.7 \%)$ and March $(8.2 \%)$ which are in the dry season and September $(8.9 \%)$, July $(8.6 \%)$, June $(8.1 \%)$, August $(7.7 \%)$ and October $(7.1 \%)$ in the wet season. This agrees with the findings of Abayomi (2016). From this result, more cases of parvovirosis were observed in the dry (January, February, November and December) season as compared to the wet (June, July and October) season. This agrees with the findings of Shima et al. (2015a) but disagrees with Tion et al. (2018) who recorded more cases of parvovirosis in the wet than the dry season. Generally, there was all year round incidence of infection which agrees with the report of Kalli et al. (2010). Dipeolu (1975) reported that the highest number of parasites occurred in summer in Nigeria. The month of February had the highest recorded frequency for myiasis infestation. This coincides with the beginning of the warm or hot season when most flies breed. Myiasis can occur in any season of the year but could be more prevalent when the weather is warmest, while wet and dirty environment, long hair-coat, untended wounds, excrements, matted hair, and owner ignorance can predispose to myiasis infestation (Anderson \& Huitson, 2004). Investigation on the seasonal distribution (months) of ectoparasites revealed that all species were present all year round. An increase in number was observed from June to December; which coincided with the period of intensive rainfall and early part of dry season. However, a gradual decline in parasite abundance was noticed from February to May, a period characterized by high temperature. Similar findings were reported in Nigeria (Shoorijeh et al., 2008; Arong et al., 2011; Konto et al., 2014).

Mange is a highly contagious, intensely pruritic and potentially zoonotic skin condition of animals. It is caused by infestation of the skin by a mite, Sarcoptes scabiei var. canis (Anita \& Peter, 2008) which burrows into its hosts epidermis. Mange is known to be most active in the rainy season but improves slightly during the dry season (Olubunmi, 1995; Soulsby, 1998). This disagrees with the finding from this study.

Dry seasons don't favor parasites and their eggs owing to harsh weather conditions which make wet season favorable for their multiplication and infestation. Reports have shown that, most ectoparasites (ticks) cannot tolerate direct sunlight, dryness, or excessive rainfall decreases their activities during the cold months and increases during spring, summer, and fall in the temperate regions (Ballweber, 2001). From this study, high prevalence of ectoparasites and babesiosis recorded during the wet season against dry season agrees with the above statement.

There was high incidence of scepticemia observed in both the dry and wet seasons. It has been documented that cold weather sometimes causes decrease activities of the immune system while supporting the proliferation of pathogens, which gain advantage of the weakened immune status to invade and cause septicemia in the host.
It has been reported that initiation of a respiratory disease may not be related to cold weather rather cold weather may exacerbate disease symptoms (Heikki Olavi, 2007).

In Table 6, the minimum, mean and maximum frequencies of occurrence of clinical cases/conditions are recorded.

\section{Conclusion}

Most the infectious clinical cases/conditions recorded from this study are preventable cases. Puppies (0-6 months old) $50.2 \%$ were mostly affected; Alsatians $(23.7 \%)$ had the highest incidence of cases/conditions followed by Cross $(22.9 \%)$, Nigerian indigenous breed (20.5\%), Caucasian (9.6\%) and Rottweiler (8.9\%). Vaccinated (68.7\%) and male (57.1\%) dogs had high frequency of cases. Disease incidence was highest in dry $(51.9 \%)$ season especially in the months of December (13.3\%), January (11.1\%) and February (10.6\%). The highest frequency of disease incidence was recorded in $2015(36.4 \%)$. When veterinary attention/care is given to animals, such conditions will be curtailed and prevented in the lives of our dogs and the risk of zoonosis will also be reduced.

\section{Acknowledgement}

The authors wish to thank the managements of various veterinary clinics in Benue (Veterinary Teaching Hospital and Greenflash Veterinary Clinic Makurdi), Plateau (Apex Veterinary Clinic, Hat Veterinary Clinic, and Shalom Veterinary Clinic, Jos) and Abuja (El-mond Veterinary Services, Abuja) for being generous enough to give us access to their records.

\section{References}

Abayomi, K.O. (2016). Prevalence and Seasonal Variation of Parasitic Diseases in Dogs Presented at Small Animal Clinic of Veterinary Teaching Hospital, University of Ibadan, Ibadan, Nigeria Between 2001 And 2005. International Journal of Livestock Research, 6(12), 39-45. doi: 10.5455/ijlr.20161205033033.

Aiyedun, J.O., \& Olugasa, B.O. (2012). Identification and analysis of dog use, management practices and implications for rabies control in Ilorin, Nigeria. Sok. J. Vet. Sci., 10(2), 1-6. doi: 10.4314/sokjvs.v10i2.1.

Alcaino, H.A., Gorman, T.R., \& Alcaino, R., (2002). Flea species from dogs in three cities of Chile. Vet. Parasitol., 105(3), 261-265. doi: 10.1016/ s0304-4017(01)00626-4.

Anderson, G.S., \& Huitson, N.R. (2004). Myiasis in owned animals in British Columbia: The potential of forensic entomology for determining the duration of possible neglect. Canadian Veterinary Journal, 45, 993-998. https://www.ncbi.nlm.nih.gov/pmc/articles/PMC55475 4.

Anita, P., \& Peter, F, (2008). Saunders Solutions in Veterinary Practice - Small Animal Dermatology (C) 2008 Elsevier Ltd. 
Anon. (2013a) Survey suggests many pets do not receive preventive healthcare. Veterinary Record, 172(22), 569. doi: 10.1136/vr.f3457.

Apaa, T.T., Daly, J.M., \& Tarlinton, R.E. (2016). Canine parvovirus (CPV-2) variants circulating in Nigerian dogs. Veterinary Record Open, 3, e000198. doi: 10.1136/ vetreco-2016-000198.

Arong, G., Shitta, K., James-Rugu, N., \& Effanga, E. (2011). Seasonal variation in the abundance and distribution of Ixodid ticks on mongrel, Alsatian and mixed breeds of dogs (Canis familiaris) in Jos, in Plateau State, North-Central Nigeria. World Journal of Science and Technology, 1(4), 24-29. https://www.ajol.info/index.php/njpar/article/view/990 95.

Ballweber, L.R. (2001). Veterinary parasitology, Butterworth-Heinemann, Woburn, USA.

Bryson, N., Horak, I., Hohn, E., \& Louw, J. (2000). Ectoparasites of dogs belonging to people in resourcepoor communities in North West Province, South Africa. J. S. Afr. Vet. Assoc., 71(3), 175-179. doi: 10.4102/jsava.v71i3.709.

Cassini, R., S., Zanutto, A., Frangipane di Regalbono, S., Gabrielli, P., Calderini, A., Moretti, M. P., Tampieri, M., Pietrobelli (2009). Canine piroplasmosis in Italy: epidemiological aspects in vertebrate and invertebrate hosts. Veterinary Parasitology 165(1-2), 30-35. doi: 10.1016/j.vetpar.2009.06.044.

Cleaveland, S., Meslin, F. X., \& Breiman, R. (2006). Dogs can play useful role as sentinel hosts for disease. Nature, 440(7084), 605-605. doi: 10.1038/440605b.

Craig, P.S., \& Macpherson, C.N.L. (2000). Dogs and cestode zoonoses. In: Macpherson, C.NL., Meslin, F. X., Wandeler, A. I. (Eds.), Dogs, Zoonoses and Public Health. CAB International, Oxon, United Kingdom, 149-211.

Day, M.J. (2012).Vaccination. In: Day MJ, editor. Clinical immunology of the dog and cat. 2nd ed. Bristol: Manson Publishing, 413-430.

Dipeolu, O.O. (1975). A survey of the ectoparasitic infestations of dogs in Nigeria. J Small Anim Pract, 16(1-12), 123-129. doi: 10.1111/j.17485827.1975.tb05725.x.

Dohoo, I.R., McDonell, W.N., Rhodes, C.S., \& Elazhary, Y.L. (1998). Veterinary research and human health. Canadian Veterinary Journal, 39(9), 548-556. https://www.ncbi.nlm.nih.gov/pmc/articles/PMC1539 426.

Faldyna, M., Leva, L., Knotigova, P., \& Toman, M. (2001). Lymphocyte subsets in peripheral blood of dogs- a flow cytometric study. Veterinary Immunology and Immunopathology, 82(1-2), 27-37. doi: 10.1016/s0165-2427(01)00337-3.

Heikki Olavi, K. (2007). Cold air-provoked respiratory symptoms: The mechanisms and management. International Journal of Circumpolar Health, 66(2), 91-100. doi: 10.3402/ijch.v66i2.18237.

Heukelbach, J., Frank, R., Ariza, L., de Sousa Lopes, Í., e Silva, A.d.A., Borges, A.C., Limongi, J.E., de Alencar, C.H.M., Klimpel, S. (2012). High prevalence of intestinal infections and ectoparasites in dogs, Minas Gerais State (southeast Brazil). Parasitol. Res. 111(5), 1913-1921. doi: 10.1007/s00436-012-3037-0.

Jensen, W., Totten, J., Lappin, M., \& Schultz, R. (2015). Use of serologic tests to predict resistance to canine distemper virus-induced disease in vaccinated dogs. $\mathrm{J}$ Vet Diagn Investig, 27(5), 576-580. doi: $10.1177 / 1040638715602291$.

Kalli, I., Leontides, L.S., Mylonakis, M.E., AdamamaMoraitou, K., Rallis, T., \& Koutinas, A.F. (2010). Factors affecting the occurrence, duration of hospitalization and final outcome in canine parvovirus infection. Research in Veterinary Science, 89(2), 174178. doi: 10.1016/j.rvsc.2010.02.013.

Kaminski, J., \& Nitzschner, M. (2013). Do dogs get the point? A review of dog-human communication ability. Learn. Motiv, 44(4), 294-302. doi: 10.1016/j.lmot.2013.05.001.

Karshima, S.N., Tizhe, E.V., \& Bukar, D.P. (2010). A retrospective study of parasitic diseases of dogs and cats in Jalingo, North-Eastern Nigeria between 1998 and 2008. Sokoto Journal of Veterinary Sciences, 8(1), 46-49. https://www.ajol.info/index.php/sokjvs/ article/view/72771.

Kennedy, L.J., Barnes, A., Happ, G.M., Quinnell, R.J., Bennett, D., Angles, J.M., Day, M.J., Carmichael, N., Innes, J.F., Isherwood, D., Carter, S.D., Thomson,W. and Ollier,W.E.R. (2002). Extensive interbreed, but minimal intrabreed, variation of DLA class II alleles and haplotypes in dogs. Tissue Antigens, 59(3), 194204. doi: 10.1034/j.1399-0039.2002.590303.x.

Kennedy, L.J., Lunt, M., Barnes, A., McElhinney, L.M., Fooks, A.R., \& Ollier, W.E.R. (2005). Do dogs vary in their response to rabies vaccination? Proceedings of the 48th Annual Congress of the British Small Animal Veterinary Association, 550.

Konto, M., Biu, A., Ahmed, M., \& Charles, S. (2014). Prevalence and seasonal abundance of ticks on dogs and the role of Rhipicephalus sanguineus in transmitting Babesia species in Maiduguri, NorthEastern Nigeria. Veterinary World, 7(3), 119-124.

McRee, A., Wilkes, R.P., Dawson, J., Parry, R., Foggin, C., Adams, H., Odoi, A., Kennedy, M.A. (2014). Serological detection of infection with canine distemper virus canine parvovirus, and canine adenovirus in communal dogs from Zimbabwe. Journal of the South African Veterinary Association, 85(1), 1-2. doi: 10.4102/jsava.v85i1.1110.

Mila, H., Grellet, A., Desario, C., Feugier, A., Decaro, N., Buonavoglia, C., \& Chastant-Maillard, S. (2014). Protection against canine parvovirus type 2 infection in puppies by colostrum-derived antibodies. J Nutr Sci., 3(e54), 1-4. doi: 10.1017/jns.2014.57.

Mohammed, J.G., Ogbe, A.O., Zwandor, N.J., \& Umoh, J.U. (2005). Risk factors associated with canine parvovirus enteritis in Vom and environs. Animal Research International, 2, 366-368. https:/www.ajol.info/index.php/ari/article/view/40870.

Nuchjangreed, C., \& Somprasong, W. (2007). Ectoparasite species found on domestic dogs from 
Pattaya district, Chon Buri province, Thailand. Southeast Asian J. Trop. Med. Public Health, 38, 203. https://www.tm.mahidol.ac.th/seameo/2007-38-suppl1/38suppl1-203.pdf.

Nwoke, B. (2001). Urbanization and livestock handling and farming: the public health and parasitological implications. Niger. J. Parasitol, 22(1), 121-128. doi: 10.4314/njpar.v22i1.37769.

Nwoha, R.I.O. (2011). Parvoviral enteritis in a dog: case report and review of the literature. Continental Journal of Veterinary Science, 5, 6-10.

Okusanya, O., Jagun, A.J.J., Adeniran, G.A., Emikpe, B.O., \& Jarikre, T. (2014). Retrospective study of diseases and associated pneumonia type diagnosed in dogs at post-mortem at Veterinary Teaching Hospital, Ibadan, Nigeria. Sokoto Journal of Veterinary Sciences, 12, 15-20. doi: 10.4314/sokjvs.v12i3.3.

Olubunmi, K. (1995). The prevalence of caprine sarcoptic mange due to sarcoptes scabie var capri in Ile-Ife Area of Nigeria, its control and management. Bulletin of Animal Health and Production in Africa, 45, 115-119. 32.

Robertson, I.D., Irwin, P.J., Lymbery, A.J., \& Thompson, R.C.A. (2000). The role of companion animals in the emergence of parasitic zoonoses. International Journal for Parasitology, 30(1213), 1369-1377. doi: 10.1016/s0020-7519(00)00134-X.

Schreiber, M., Kantimm, D., Kirchho, D., Heimann, G. and Bhargava, A. S. (1992). Concentrations in serum of IgG, $\operatorname{IgM}$ and $\operatorname{IgA}$ and their age-dependence in beagle dogs as determined by a newly developed enzyme-linked immunosorbent assay (ELISA). European Journal of Clinical Chemistry and Clinical Biochemistry, 30(1), 775-778. doi: 10.1515/cclm.1992.30.11.775.

Schultz, R.D., Thiel, B., Mukhtar, E., Sharp, P., Larson, L.J. (2010). Age and long-term protective immunity in dogs and cats. J Comp Pathol, 142, 102-108. doi: 10.1016/j.jcpa.2009.10.009.

Shima, F., Apaa, T., \& Mosugu, J.T. (2015). Epidemiology of Canine Parvovirus Enteritis among Hospitalized Dogs in Effurun/Warri Metropolitan Region of Delta State, Nigeria. Open Access Library Journal, 2, 1-7. doi: 10.4236/oalib.1101208.
Shima, F.K., Gberindyer, F.A., Apaa, T.T., Mosugu, J.I. (2015a). Clinico-epidemiological study on canine toxicosis in Effurun/Warri municipality region of Delta State, Nigeria. Journal of Advanced Veterinary and Animal Research, 2, 357-361. doi: 10.5455/javar.2015.b91.

Shoorijeh, S.J., Ghasrodashti, A.R., Tamadon, A., Moghaddar, N., \& Behzadi, M.A. (2008). Seasonal frequency of ectoparasite infestation in dogs from Shiraz, Southern Iran. Turkish Journal of Veterinary and Animal Sciences, 32(4), 309-313.

Soulsby, E.J.L. (1998). Helminths, Arthropods and Protozoa of Domestic Animals, Bailliere, Tindall and Easel Ltd, London, 465-469.

Tion, M.T., Apaa, T.T., Saganuwan, A.S., Nwankwo, H.C., Tughgba, T., Anumtyo, T.M., Amine, A.A., Nguetyo, S.A., Igoh, A.F., \& Akpehe-Ishor, W. (2018). The Epidemiology of Canine Parvovirus Enteritis in Dogs of Makurdi, Benue State, Nigeria. World Vet. J., 8(3), 48-54. http://www.wvj.scienceline.com/attachments/article/53/WVJ\%208(3)\%204854,\%20Sep \%2025,\%202018.pdf.

Thalmann, O., Shapiro, B., Cui, P., Schuenemann, V.J., Sawyer, S.K., Greenfield, D.L., Germonpré, M.B., Sablin, M.V., López-Giráldez, F., Domingo-Roura, X. et al. (2013). Complete mitochondrial genomes of ancient canids suggest a European origin of domestic dogs. Science, 342(6160), 871-874.

Traub, R., Robertson, I., Irwin, P., Mencke, N., \& Thomson, R. (2005). Canine gastrointestinal parasitic zoonoses in India. Trends in Parasitology, 21(1), 4248. doi:10.1016/j.pt.2004.10.011.

Toman, M., Faldyna, M., Knotigova, P., Pokorova, D. and Sinkora, J. (2002). Postnatal development of leukocyte subset composition and activity in dogs. Veterinary Immunology and Immunopathology, 87, 321-326. doi: 10.1126/science. 1243650.

William, A., Chaudhari, S. U. R., Atsanda, N. N. (2002). Prevalence of some diseases of dogs and cats at the State Government Veterinary Clinic in MaiduguriNigeria. International Journal of Agriculture and Biology, 4, 568-569. 